\title{
Detection and characterization of endophytic bacteria causing knot in young olive trees
}

\author{
Maryam KHEZRI ${ }^{1}$, Abolghasem GHASEMI ${ }^{2}$, Akbar AHANGARAN ${ }^{3}$
}

Received August 10, 2018; accepted January 28, 2019.

Delo je prispelo 10. avgusta 2018, sprejeto 28. januarja 2019.

\begin{abstract}
Olive knot is an important disease in most countries where olives are commercially grown. In the spring of 2015, some galls were observed on the trunk and branches of 4-year-old olive trees in the north of Iran. The bacteria were isolated from galls and all isolates were gram-negative, aerobic, and capable of producing florescent pigment. Other phenotypic characteristics of the isolates were assessed. Pathogenicity tests were carried out on olive branches incubated with different isolates. Primary symptoms were observed after two weeks. Sequences of $16 \mathrm{~S}$ rRNA and RNA polymerase beta subunit genes of pathogenic isolates were completely similar to Pseudomonas savastanoi pv. savastanoi (Smith 1908) Young et al. 1978 in GenBank. Based on the results from phenotypic analyses, pathogenicity tests and phylogenetic data, the isolates were identified as $P$. savastanoi $\mathrm{pv}$. savastanoi. The host range of our isolates was specific to olive trees. None of the inoculated oleander (Nerium oleander L.), winter jasmine (Jasminum nudiflorum Lindl.), Japanese privet (Ligustrum japonicum Thunb.) and ash (Fraxinus excelsior L.) developed disease symptoms. No difference in disease resistance was observed between six studied olive cultivars. There was no olive tree or orchard around the studied orchard as far as more than one kilometer. As the disease agent listed in Iran's foreign quarantine pests and diseases list, appropriate quarantine and phytosanitary measures were undertaken to eradicate the disease.
\end{abstract}

Key words: Pseudomonas savastanoi pv. savastanoi; Phenotypic identification; 16S rRNA, rpoB; cultivar resistance

\section{IZVLEČEK \\ DOLOČANJE IN OPIS ENDOFITSKIH BAKTERIJ, KI POVZROČAJO OLJKOVEGA RAKA NA MLADIH OLJKAH}

Oljkov rak je pomembna bolezen v vseh deželah, kjer gojijo oljke. Spomladi leta 2015 so bili v severnem Iranu na deblih in vejah štiriletnih oljk opaženi tumorji. Iz njih so bile izolirane gram negativne bakterije, ki so bile sposobne tvoriti fluorescentni pigment. Ocenjene so bile tudi druge fenotipske lastnosti izolatov. Test patogenosti različnih izolatov je bil opravljen na oljčnih vejah. Prva bolezenska znamenja so se pojavila po dveh tednih. Zaporedja $16 \mathrm{~S}$ rRNK in genov beta podenote RNK polimeraze iz patogenih izolatov so bila popolnoma podobna tistim iz bakterije Pseudomonas savastanoi pv. savastanoi (Smith 1908) Young et al. 1978, iz GenBank. Na podlagi rezultatov fenotipskih analiz, testov patogenosti in filogenetskih podatkov so bili izolati določeni kot vrsta $P$. savastanoi pv. savastanoi. Gostitelji izoliranih bakterij so bile samo oljke. Na nobeni od inokuliranih drugih vrst, kot so zimski jasmin (Jasminum nudiflorum Lindl.), navadni oleander (Nerium oleander L.), japonska kalina (Ligustrum japonicum Thunb.) in veliki jesen (Fraxinus excelsior L.), se niso razvila bolezenska znamenja. Med šestimi preučevanimi sortami oljk ni bilo razlik v odpornosti proti bolezeni. V okolici preučevanega oljčnika ni bilo $\mathrm{V}$ razdalji več kot kilometer nobene oljke, niti oljčnika. Povzročitelj bolezni je $\mathrm{v}$ Iranu na seznamu tujerodnih karantenskih škodljivcev in bolezni, zato so bili sprejeti ustrezni karantenski in fitosanitarni ukrepi za izkoreninjenje bolezni

Ključne besede: Pseudomonas savastanoi pv. savastanoi; fenotipska identifikacija; $16 \mathrm{~S}$ rRNA, rрoв; sortna odpornost

\footnotetext{
1 Department of Plant Protection, Faculty of Agriculture, Urmia University; *corresponding author: m.khezri@urmia.ac.ir

2 Department of Plant Pathology Research, Iranian Research Institute of Plant Protection (IRIPP), Tehran, Iran

3 Bureau of Plant Quarantine, Plant Protection Organization (PPO), Tehran, Iran
} 


\section{INTRODUCTION}

Pseudomonas savastanoi Smith 1908) Young et al. 1978 includes four pathovars; $P$. savastanoi pv. savastanoi, pv. nerii, pv. fraxini, and pv. retacarpa that cause knot or excrescences in olive (Olea europaea L.), oleander (Nerium oleander L.), common ash (Fraxinus excelsior L.), and Spanish broom (Retama sphaerocarpa L.), respectively (Caballo-Ponce et al., 2017). In addition, bacterial agents of soybean brown spot and halo blight disease on bean are P. savastanoi pv. glycinea and $P$. savastanoi pv. phaseolicola, respectively (Addy \& Wahyuni, 2016; Marques \& Samson, 2016).

The gamma proteobacterium $P$. savastanoi pv. savastanoi (here after Psv) causes olive knot disease. The disease is one of the most economically relevant diseases of the olive trees and cause serious reduction in crop yields (Agrios, 2005; Campos et al., 2009). Olive knot represents a serious disease in many oliveproducing areas, which can cause a progressive plant decline that leads to reduction in the number of fruitbearing shoots and tree yield potential (Quesada et al., 2010). Disease symptoms are characterized by tumorous outgrowths, called knot or gall. The knots appear on different parts of the plant, mainly on twigs and young branches (Ramos et al., 2012). Olive knot disease seriously affects olive trees mainly in Mediterranean countries, where climatic conditions often favor spread of the disease. The development of these galls results from uncontrolled cell growth due to disruption in plant hormone balance. Gall appearance is dependent on auxin phytohormone, indole-3-acetic acid (IAA), produced by pathogenic bacteria (Kieffer et al., 2010). Produced IAA can interfere with plant development by disturbing the auxin balance in plants (Caballo-Ponce et al., 2017). Several auxin biosynthetic pathways in plant galls forming bacteria have been described, which are mostly dependent on L-tryptophan as a precursor (Spaepen et al., 2007).
It has been reported that olive knot formation is $\mathrm{hrp} / \mathrm{hrc}$ dependent (Sisto et al., 2004) and biosynthesis of auxin has been described as a pathogenicity or virulence factor (Patten et al., 2013). The other phytohormones involved in gall production are cytokinins (CKs) such as zeatin, dihydrozeatin, 1-methyl-zeatin, ribosylzeatin, ribosyldihydrozeatin, and ribosyl-1-methylzeatin, as well as diverse methylated zeatin derivatives (CaballoPonce et al., 2017). Some of the functions that are attributed to these hormones are control of different processes in plant growth and development of plant defenses against stresses (O’Brien \& Benkova, 2013).

In recent years, there has been an increasing interest in olive cultivation in many countries probably due to the olive oil benefits for human health. The bacterium lifestyle in olive knots has already been described in greater detail (Rodriguez-Moreno et al., 2009). In saprophytic phase, Psv can duplicate on phylloplane of the olive tree (Quesada et al., 2007) and spreads by windblown aerosols, splashing rain and cultural practices at short distances. Wounds caused by insects, pruning and harvest create entry sites through which infection can occur (Quesada et al., 2010). Secondary tumors develop with migration of the pathogen within the host (Penyalver et al., 2006; Marchi et al., 2009). The bacterium can also survive in side knots from one season to the next. Efficient control of olive knot disease is based on the preventive measures (Quesada et al., 2010; Ramos et al., 2012). Recently, schemes for the production of certified olive plants free from bacteria and other pathogens, including Psv have been published (EPPO, 2006).

Olive tree cultivation has expanded in recent years in different parts of Iran as well as in many other countries. In the current study, bacterial agent of olive knot detected in a young orchard was phenotypically and genotypically characterized. Then, pathogen host range and susceptibility to olive knot disease was evaluated in common olive cultivars.

\section{MATERIAL AND METHODS}

\subsection{Sampling procedures and the bacterial pathogens isolation}

In spring of 2015, galls were observed on trunk and branches of 4-year-old olive trees in an orchard in Golestan province, located in the north of Iran. Sampling was carried out by cutting knots from different trees. The knots were placed in plastic bags, transported to the laboratory and processed immediately. The knots were surface-disinfected with a paper moistened with ethanol $70 \%$ (Marchi et al., 2005). Small fragments $(1-2 \mathrm{~mm})$ were cut aseptically with a sterile scalpel then placed in one $\mathrm{ml}$ of sterile distilled water (SDW). After $20 \mathrm{~min}$, a loopful of the resulting suspension was streaked on plates containing King's B medium (KB), and then incubated at $26^{\circ} \mathrm{C}$ for 3-5 days. Single colonies were collected and checked for purity. A total of nineteen isolates, PS01-PS19, were obtained from olive knots. A reference strain from 
Instituto Valenciano de Investigaciones Agrarias (IVIA 1657-8) was used in all phenotypical and biochemical analyses.

\subsection{Phenotypical characterizations of isolates}

Physiological and biochemical characteristics of the isolates were determined by standard bacteriological methods including: gram-stain reaction, fluorescent pigment production on KB medium, colony morphology on nutrient agar (NA), levan, oxidase, pectinolytic activity, arginine dehydrolase, and tobacco hypersensitivity reaction (LOPAT) according to Lelliott et al. (1966). Tween 80 hydrolysis, indole production with Kovac's reagent, catalase reaction, nitrate reduction, starch hydrolysis, growth at $37^{\circ} \mathrm{C}$, growth in general media containing 3, 5 and $7 \%\left(\mathrm{wv}^{-1}\right) \mathrm{NaCl}$, gelatin liquefaction, esculin and casein hydrolysis, $\mathrm{H}_{2} \mathrm{~S}$ production from L-cysteine and reducing compounds from sucrose based on Schaad et al. (2001). In addition, utilization of sugars and amino acids as a sole carbon and nitrogen source by studied isolates was evaluated.

\subsection{Pathogenicity tests}

A pathogenicity test was performed for all studied isolates. Bacterial suspension was prepared from pure culture $\left(10^{8} \mathrm{CFU} \mathrm{ml}{ }^{-1}\right)$ grown for $48 \mathrm{~h}$ on $\mathrm{KB}$ medium. Wounds of around one $\mathrm{cm}$ were cut in the bark of oneyear-old olive stems and inoculated directly with a scalpel dipped in bacterial suspension or bacterial colony. Each isolate was inoculated at five wounding sites. Wounds were protected with parafilm for three days. The inoculated trees were kept in a greenhouse at $25^{\circ} \mathrm{C}$ and inspected for knot formation for four months. Negative control trees were inoculated with phosphate buffered saline (PBS).

\subsection{DNA extraction}

Bacterial isolates were grown for $48 \mathrm{~h}$ at $26{ }^{\circ} \mathrm{C}$ on $\mathrm{KB}$ medium. DNA was extracted from bacterial suspensions $\left(10^{9} \mathrm{CFU} \mathrm{ml}{ }^{-1}\right)$ using the protocol described by Llop et al. (1999). The DNA was dissolved in SDW before quantification by spectrophotometer and kept at $-20{ }^{\circ} \mathrm{C}$ until use. In the direct isolation method, bacterial suspension was adjusted to $10^{7}-10^{8} \mathrm{CFU} \mathrm{ml}^{-1}$ in SDW. After adding $100 \mu \mathrm{l}$ of $0.05 \mathrm{M} \mathrm{NaOH}$ to $10 \mu \mathrm{l}$ bacterial suspension, sample incubated at $95^{\circ} \mathrm{C}$ for $15 \mathrm{~min}$, and $2 \mu \mathrm{l}$ of the boiled suspension was used as template for the PCR tests (Rademaker \& de Bruijn, 1997).

\subsection{PCR amplification}

Molecular identification of bacterial isolates was carried out using a universal primer pair for amplification of 16S rRNA fD1 (5'-AGAGTTTGATCCTGGCTCAG3') and rP2 (5'-ACGGCTACCTTGTTACGACTT-3') in a standard PCR assay (Weisburg et al., 1991). PCR reactions were performed in a $20 \mu \mathrm{l}$ PCR mixture containing 1X PCR buffer (Fermentas, Germany), $3 \mathrm{mM} \mathrm{MgCl}, 0.2 \mathrm{mM}$ of each deoxynucleoside triphosphates, $10 \mathrm{pM}$ of each primer, $1 \mathrm{U}$ Taq DNA polymerase and $50 \mathrm{ng} \mu^{-1}$ of template DNA. PCR amplification was carried out under the following conditions: initial denaturation cycle at $94{ }^{\circ} \mathrm{C}(5 \mathrm{~min})$, 35 cycles at $94{ }^{\circ} \mathrm{C}(1 \mathrm{~min}), 62{ }^{\circ} \mathrm{C}(1 \mathrm{~min})$ and $72{ }^{\circ} \mathrm{C}$ (1.5 min), and then one cycle at $72{ }^{\circ} \mathrm{C}$ for 7 minutes in a Bio-Rad thermal cycler.

Amplification of $r p o B$ gene with oligonucleotide primer pair LAPS (5'-TGGCCGAGAACCAGTTCCGCGT-3') and LAPS27 (5'-CGGCTTCGTCCAGCTTGTTCAG$3^{\prime}$ ) was used in a standard PCR assay (Tayeb et al., 2005). PCR reactions were performed in a $20 \mu \mathrm{l}$ PCR mix contained 1X PCR buffer (Fermentas, Germany), $3 \mathrm{mM} \mathrm{MgCl}, 0.2 \mathrm{mM}$ of each deoxynucleoside triphosphates, $10 \mathrm{pM}$ of each primer, $1 \mathrm{U}$ Taq DNA polymerase and $50 \mathrm{ng} \mu \mathrm{l}^{-1}$ of template DNA. PCR amplification was carried out under following condition: initial denaturation cycle at $94{ }^{\circ} \mathrm{C}(5 \mathrm{~min}), 40$ cycles at $94{ }^{\circ} \mathrm{C}(10 \mathrm{~s}), 50^{\circ} \mathrm{C}(20 \mathrm{~s})$ and $72{ }^{\circ} \mathrm{C}(50 \mathrm{~s})$, and then one cycle at $72{ }^{\circ} \mathrm{C}$ for 5 minutes in a Bio-Rad thermal cycler. Six $\mu$ of amplified products were separated by electrophoresis on a $1 \%$ agarose gel, stained with ethidium bromide and photographed by a gel documentation system. After staining, the results were observed using gel-document (Syngene, USA). Purification of amplified DNA fragments was done with a high pure PCR product purification kit (Roche, Germany) and Sanger sequenced (Macrogen, South Korea).

\subsection{Phylogenitic analysis}

The 16S rRNA and rpoB sequences were compared with available sequences in GenBank using the BLAST search algorithm at NCBI. Alignments were built in ClustalW (Thompson et al., 1994), and subsequently adjusted manually in BioEdit Ver.7.0.9 (Hall, 1999). Phylogenetic relations were inferred from applying the Kimura-2-parameter model (Kimura, 1980) with the neighbor joining (NJ) algorithm (Saitou \& Nei, 1987) implemented in MEGA7. The branch support was assessed by computing 1000 bootstrap estimates (Tamura et al., 2007).

\subsection{Cultivar susceptibility}

Two-year-old plants of six olive cultivars (Olea europaea 'Arbequina', 'Arbosana', 'Beldi', 'Koroneiki', 'Manzanilla' and 'Mission') were used for the evaluation of cultivar susceptibility to Psv. The plants were wounded at five sites on the main stem and inoculated with five pathogenic strains (PS1, PS3, PS6, PS10 and PS17), separately. Three plants per cultivar were used (75 sites were inoculated per each cultivar). The 
bacterial suspensions were made in phosphate PBS and concentration was adjusted to $10^{8} \mathrm{CFU} \mathrm{ml}{ }^{-1}$. Bacterial suspension of $100 \mu \mathrm{l}$ was injected tangentially into the bark using a sterile needle, and then the hole was covered with parafilm for three days. The negative control plants were inoculated with PBS only. The plants were kept in a greenhouse at $23-26^{\circ} \mathrm{C}$ and 75 $80 \% \mathrm{RH}$. The disease symptom development was monitored for four months after inoculation. The disease response for each cultivar was evaluated as the proportion of inoculated wound sites developing knots after three months after post inoculations (Penyalver et al., 2006).

\subsection{Hosts range test}

One and two-year old olive (Olea europaea L.), oleander (Nerium oleander L.), winter jasmine (Jasminum nudiflorum Lindl.), Japanese privet (Ligustrum japonicum Thunb.) and common ash (Fraxinus excelsior L.) plants were used for determining host range. Inoculation was performed for cultivar susceptibility, as described above. The plants incubated with PBS were used as negative controls (Iacobellis, 2001).

\section{RESULTS AND DISCUSSION}

Olive knot disease is one of the important diseases caused by $P$. savastanoi pv. savastanoi, which can cause significant yield losses. Psv survives epiphytically and penetrates through the wounds, particularly through leaf scars and mechanically caused wounds (e.g. pruning), where bacterial infections and colonization result in a knot formation (Quesada et al., 2010). The typical knot of this disease is caused by phytohormones produced by the bacteria, which cause proliferation of cells surrounding the infection area. Olive knot is present mainly in Mediterranean countries, where climatic conditions often favor the spread of the disease (Moretti et al., 2017). During the research which was conducted in the spring of 2015, we found knot symptoms on trunk and branches of 4-year-old olive trees in the north of Iran. To identify and characterize the bacterial disease agent, we phenotypically and genotypically characterized the pathogenic isolates. In addition, host range and cultivar susceptibility to the disease of common olive varieties were determined.

\subsection{Symptomatology and phenotypic identification of the isolates}

The galls on trunk and branches were spherical, pale green to brown in color and had a smooth surface (Figure 1). A total of 19 bacterial isolates were recovered from olive galls. Remarkable similarities were observed among isolates in morphological, biochemical and physiological characteristics.

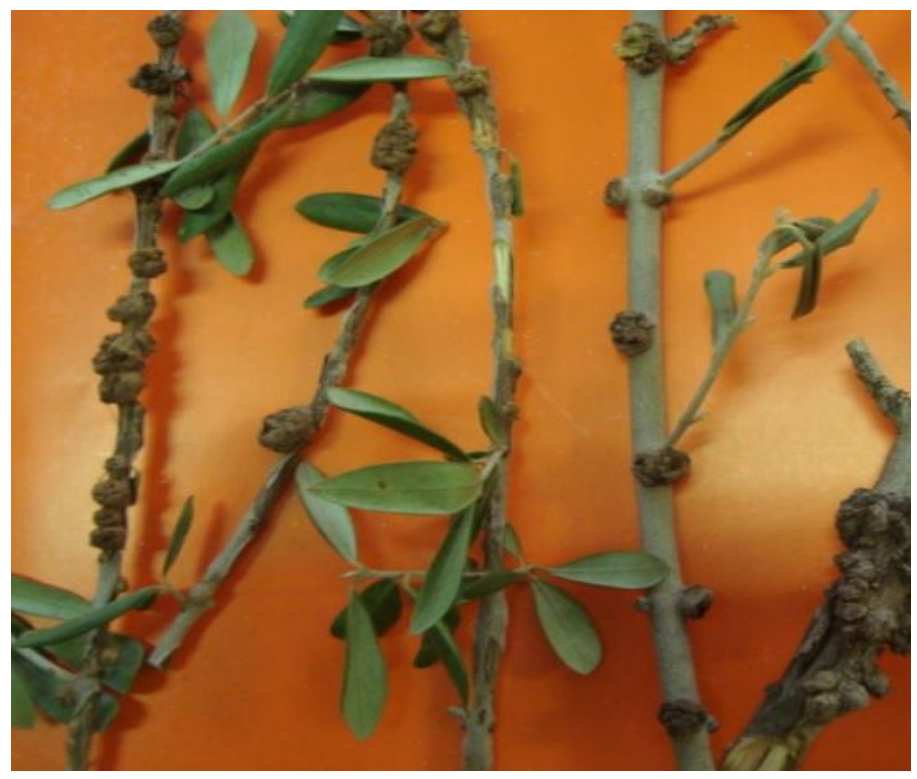

Figure 1: Gall formation on branches as a symptom of olive knot disease 
In phenotypic studies, the similarity among the isolates was at least $80 \%$. All isolates were gram-negative and aerobic, able to produce florescent pigment on $\mathrm{KB}$ medium, levan positive and showed hypersensitive reaction on tobacco leaves. The tests for oxidase, potato soft rot and arginine dihydrolase activity were negative. All studied isolates were negative in additional phenotypic tests such as starch hydrolysis, $\mathrm{H}_{2} \mathrm{~S}$ production from L-cysteine, indole production, cysteine hydrolysis, growth on media containing 3, 5 and $7 \%$ $\left(\mathrm{wv}^{-1}\right) \mathrm{NaCl}$, reducing compounds from sucrose and hydrolysis of casein, gelatin, esculin and tween 80 . The isolates were positive in catalase, nitrate reduction, urease, tyrosinase and growth at $37{ }^{\circ} \mathrm{C}$. The studied isolates utilized some sugars and amino acids as a sole carbon and nitrogen source as well. The phenotypic, biochemical and nutritional characteristics of the isolates are listed in Table 1. According to the results, all isolates belonged to one species, and no particular grouping based on biochemical and physiological characters was found. Phenotypic features of studied isolates were similar to Psv strains isolated from other countries as described before (Penyalver et al., 2000; Campos et al., 2009; Krid et al., 2009). Taghavi and Hassani (2012) detected P. savastanoi from winter jasmine, a member of the Oleaceae family, with gall symptoms on shoots from Fars province in Iran. Phenotypic characteristics of the disease agent were similar to characteristics of our isolates, except that the isolates from this study did not produce levan polymer unlike the isolates from winter jasmine where levan production was variable. Result from another study in Italy showed that bacterial agents of olive knot were levan-positive; therefore, they suggested that the production of levan polymer can be variable among Psv stains (Marchi et al., 2005). In sugars utilization capacity, bacterial isolates from this study used sucrose and sorbitol as sole carbon sources, but in previous reports from Iran the $P$. savastanoi isolated from oleander and winter jasmine did not use these sugars (Ghasemi et al., 2006; Taghavi \& Hasani, 2012).

Table 1: Phenotypic and biochemical characteristics of all studied strains

\begin{tabular}{|c|c|c|c|}
\hline Characteristic & Response & Characteristic & Response \\
\hline Gram staining & - & $\mathrm{H}_{2} \mathrm{~S}$ production & \\
\hline Anaerobic growth & - & L-cysteine & \\
\hline Fluorescent pigment on KB & + & Indole production & \\
\hline Tobacco hypersensitive reaction & + & Cysteine hydrolysis & \\
\hline Catalase activity & + & Nitrate reduction & \\
\hline Levan production & - & Urease & \\
\hline Oxidase reaction & - & Tyrosinase & \\
\hline Potato soft rot & - & Protease & \\
\hline Arginine dihydrolase & - & Reducing compounds from sucrose & \\
\hline Tobacco hypersensitive reaction & + & Utilization of: & \\
\hline Hydrolysis of: & & Adonitol, Cellobiose, Erythritol, & \\
\hline Starch & - & DL- Homoserine, Sorbitol, & + \\
\hline Casein & - & Sucrose, L-Rhamnose, D- Trehalose & \\
\hline Esculin & - & & \\
\hline Gelatin & - & Arabinose, Citrate, Inositol, & \\
\hline Tween 80 & & $\begin{array}{l}\text { Mannitol, Melibiose, D-Tartrate, L- Tartrate, } \\
\text { Xylose }\end{array}$ & - \\
\hline $3,5,7 \% \mathrm{NaCl}$ tolerance & - & & \\
\hline
\end{tabular}

\subsection{Phylogenetic analyses}

The 16S rRNA is the most common gene used in phylogenetic analyses, because of its ubiquity, essential function and evolutionary properties. In addition, multiple copies of this gene with different nucleotide sequence are often present in a bacterium. Phylogenetic analysis based on $16 \mathrm{~S}$ rRNA is widely used for identification of bacterial genera (Case et al., 2007; Krid et al., 2009; Rajwar \& Sahgal, 2016). However, studies have shown that bacterial phylogeny reconstruction using 16S rRNA gene alone does not accurately describe the diversity of microbial community. As a result, alternative housekeeping genes such as the RNA polymerase beta subunit gene (rpoB), ATP synthase beta chain $(a t p D)$, DNA gyrase beta subunit $($ gyrB $), 70$ $\mathrm{KDa}$ heat shock protein $(\operatorname{dnaK})$ and recombinase A $(r e c A)$ have been used together with $16 \mathrm{~S}$ to determine prokaryotes phylogeny (Case et al., 2007; Rajwar \& Sahgal, 2016).

Genotypic identification of pathogenic isolates was performed based on two housekeeping genes, 
16S rRNA and rpoB. We successfully amplified an expected 1500-bp band of 16S rRNA gene from all studied isolates (Figure 2). All 16S rRNA sequences had $100 \%$ similarity with those of Psv strains from GeneBank Database. The partial 16S rRNA sequences of 1377-bp and 1259-bp obtained from isolates PS06 and PS17 were deposited in GenBank under accession numbers MG930024 and MG930040, respectively.

Another gene used in this study was rpoB, one of the core housekeeping genes. We successfully amplified an expected 1247-bp band of rpoB gene in all studied isolates (Figure 3). Based on rpoB sequences, we identified the $P$. savastanoi isolates. All rpoB sequences shared $100 \%$ similarity with the Psv strains from GenBank. The partial sequences of 1046-bp obtained from PS06 and PS17 were deposited in GenBank under accession numbers MF695102 and MF695103, respectively.

The phylogenetic tree was reconstructed using two studied Psv isolates (PS06 and PS17), Psv and other Pseudomonas sequences deposited in GenBank. The sequences of $P$. viridiflava (Burkholder 1930) Dowson 1939 (JQ267553) were used as an out-group (Figure 4). Phylogenetic tree indicated that our isolates cluster together with $P$. savastanoi (AJ717422) and $P$. savastanoi $\mathrm{pv}$. savastanoi (CP008742). These isolates were located in a separate branch from other species and pathovars of pseudomonads (Figure 4). This result confirmed that rpoB gene sequences can be applied in identification different species and pathovars of Pseudomonas. Tayeb et al. (2005) successfully identified 186 strains belonging to 75 species of Pseudomonas sensu stricto and related species based on $r p o \mathrm{~B}$ gene sequences. Now, $r p o B$ gene is used routinely for identification of Pseudomonas species. Analysis of $16 \mathrm{~S}$ rRNA and rpoB genes partial sequences of 66 fluorescent pseudomonads strains revealed that phylogenetic resolution of the $r р о B$ tree was higher than that of the 16S rRNA tree (Mehri et al., 2013). Furthermore, rроB gene sequence analysis has been implemented in identification schemes of several other bacterial species (Renesto et al., 2000; Benie et al., 2016).

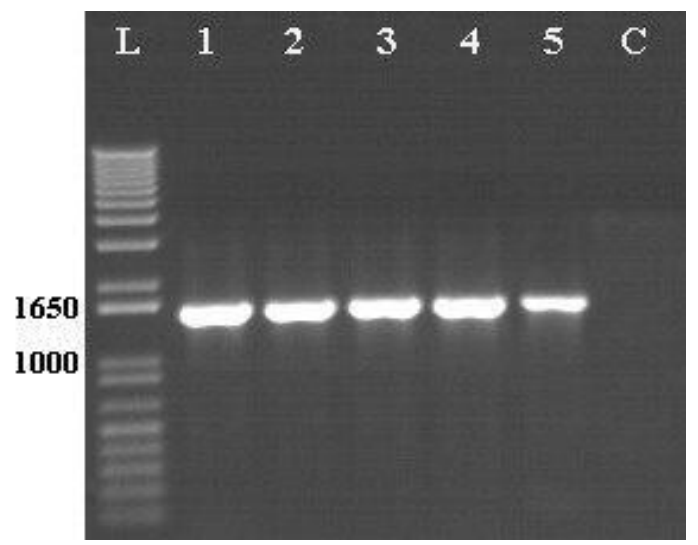

Figure 2: The visualization of PCR amplification product from 16S rRNA gene of $P$. savastanoi pv. savastanoi strains isolated from olive trees. Size of the expected product was $1500 \mathrm{bp}$. L) Ladder, 1) PS01, 2) PS04, 3) PS06, 4) PS17, 5) PS18, and C) water as negative control

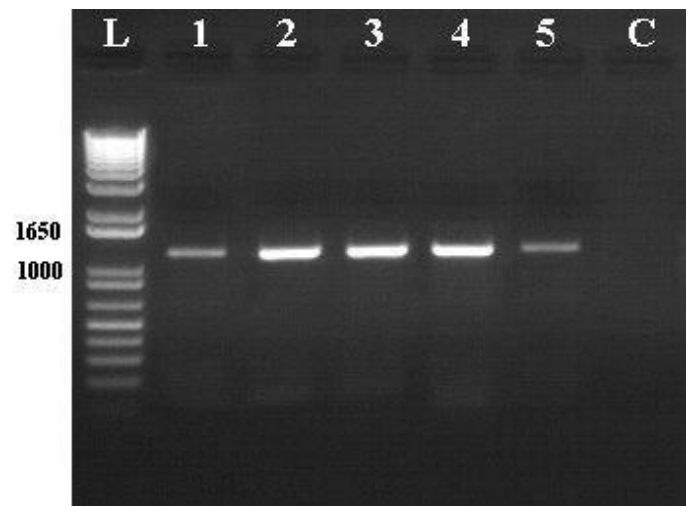

Figure 3: The visualization of PCR amplification product from rpoB gene of $P$. savastanoi pv. savastanoi strains isolated from olive trees. Size of the expected product was 1247 bp. L) Ladder, 1) PS03, 2) PS06, 3) PS12, 4) PS14, 5) PS17, and C) water as negative control 


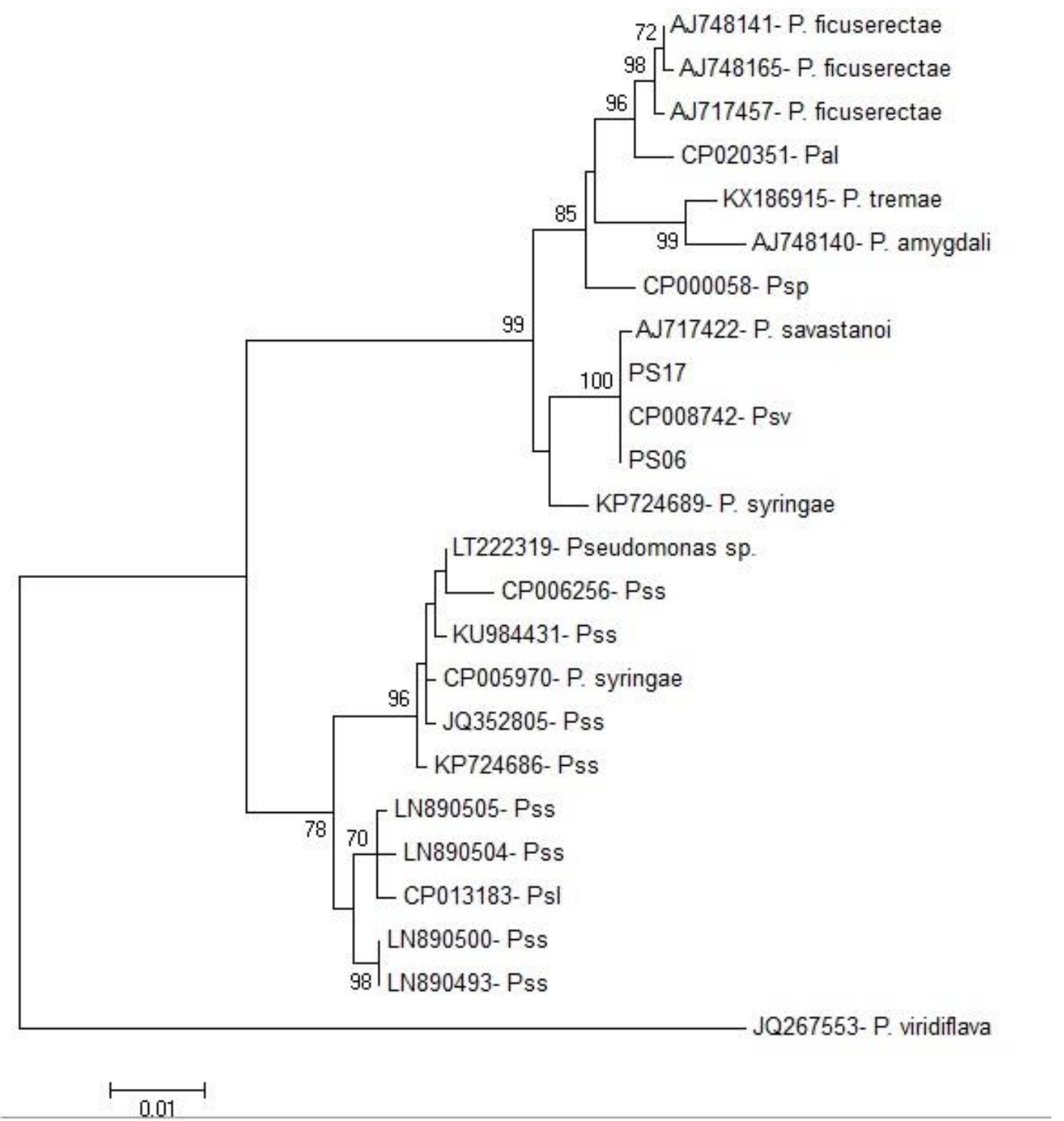

Figure 4: Phylogenetic relationship of bacterial strains isolated from olive trees based on the nucleotide sequences of the rpoB gene. PS06 and PS17 are isolates from our study, Psv (P. savastanoi pv. savastanoi), Pal (P. amygdali pv. lachrymans), Psp ( $P$. savastanoi pv. phaseolicola), Pss ( $P$. syringae pv. syringae) and Psl ( $P$. syringae pv. lapsa). The tree was reconstructed by using the NJ method, using the genetic distances computed by using the Kimura's two-parameter model. The scale bar represents the unit length of the number of nucleotide substitutions per sites

\subsection{Pathogenicity on different hosts}

Small galls on olive branches appeared after two weeks and fully developed within three months. The bacterial pathogen was re-extracted from new galls and phenotypically characterized. No galls were formed on oleander, winter jasmine, Japanese privet and common ash shoots as well as on negative control incubated with PBS (Table 2). The absence of gall formation on other plants classifies these strains in pathovar savastanoi. Several studies have indicated the host specificity in different of $P$. savastanoi pathovars (Ghasemi et al., 2006; Tegli et al., 2011; Taghavi \& Hasani, 2012). 
Table 2: Gall formation caused by pathogenic P. savastanoi pv. savastanoi strains on shoots from different hosts

\begin{tabular}{lcc}
\hline Host & Gall formation & \\
\hline Ash & & - \\
Oleander & & - \\
Olive & & - \\
Privet & - \\
Winter jasmine & - \\
Negative control (SDW) & & - \\
\hline
\end{tabular}

\subsection{Cultivars susceptibility}

Use of tolerance or low susceptible plant cultivars is an important strategy in controlling plant diseases. There is limited information on the susceptibility of the olive varieties to olive knot disease. In the present study, we infected six olive cultivars with five pathogenic strains to evaluate the cultivar's susceptibility to the disease. Olive knot symptoms were observed on the main stem of all olive cultivars after three months. 'Arbosana', 'Mission' and 'Beldi' cultivars showed the highest susceptibility to pathogenic strains, respectively. The lowest susceptibility was observed in 'Arbequina', but there were no significant differences in the size and mass of the knot, and the time of symptom appearance in studied cultivars (Figure 5). None of control plants developed knots.

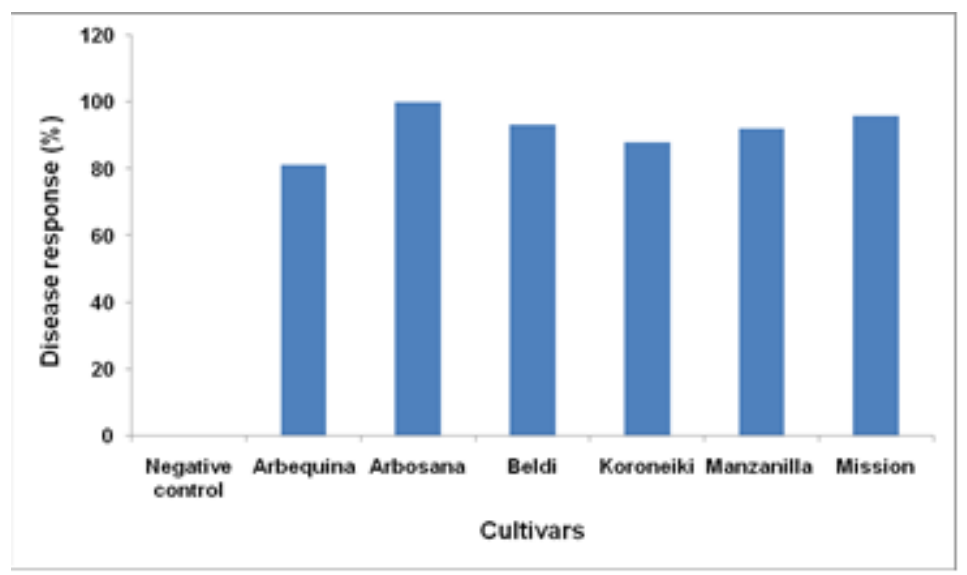

Figure 5: Proportion of wound sites developing knots on two-years-old plants of six olive cultivars. Data are shown average values of five pathogenic P. savastanoi pv. savastanoi strains (PS1, PS3, PS6, PS10 and PS17) for each cultivar. PBS was used as a negative control

Previous studies from Portugal demonstrated a slight difference in the response of olive cultivars, where the virulence ranged between 36-66 \% (Marcelo et al., 1999). Hassani et al. (2003) evaluated the severity of the symptoms by determining the size and mass of the knots after three months. They found that 'Frantoio' was the most and 'Leccino' was the least susceptible cultivar among studied cultivars. Penyalver et al. (2006) determined the proportion and mass of primary knots and the presence of secondary knots on twenty-nine olive cultivars. The cultivars were inoculated with two pathogenic strains at two inoculum doses. Their results indicated that in a low dosage inoculating, large differences in disease response were observed among cultivars infected with both pathogen strains. The proportion of sites with developed knots ranged from 0 to $100 \%$ depending on the cultivar. They also found significant differences in the presence of secondary knots among cultivars and proportion of non-inoculated sites that developed knots (from 0 to $65.5 \%$ ), depending on the cultivar. Development of primary knots and presence of secondary knots in each experiment occurred under low inoculum dose. Hence, the severity of the disease was reported to be strongly dependent on the dose of the pathogen used at the wound sites and similar to our results, none of the cultivars was resistant to the disease. 


\section{CONCLUSIONS}

Based on phenotypic and molecular characteristics, the bacterial agent causing olive knot in an orchard located in the north of Iran was Pseudomonas savastanoi pv. savastanoi. Biochemical and physiological characteristics among the isolates were similar (more than $80 \%$ ). Further, phylogenetic analysis based on rpo $\mathrm{B}$ gene confirmed the classification of the strains to pathovar "savastanoi". In biological tests, no cultivar showed resistance to the disease; however, some variation in disease susceptibility was observed. Because the bacterial olive knot disease agent belongs to Iran's list of foreign quarantine pests and diseases, appropriate quarantine and phytosanitary measures were taken to eradicate the disease in the infected orchard.

\section{REFERENCES}

Addy, H. S., \& Wahyuni, W. S. (2016). Nucleic acid and protein profile of bacteriophages that infect Pseudomonas syringae pv. glycinea, bacterial blight on soybean. Agriculture and Agricultural Science Procedia, 9, 475-481. https://doi.org/10.1016/j.aaspro.2016.02.166

Agrios, G. N. (2005). Plant Pathology. $5^{\text {th }}$ ed., New York, NY: Academic Press.

Benie, C. K. D., Dadie, A., N'Golo, D. C., Guessennd, N., Aka, S., Dje, K. M., \& Dosso, M. (2016). Comparative evaluation of molecular detection performance of Pseudomonas aeruginosa based on phylogenetic markers $16 \mathrm{~S}$ RNAr, recA, rpoB and ITS1. Clinical Microbiology, 5(6), e269. https://doi.org/10.4172/2327-5073.1000269

Caballo-Ponce, E., Murillo, J., Martinez-Gil, M., Moreno-Perez, A., Pintado, A., \& Ramos, C. (2017). Knots untie: molecular determinants involved in knot formation induced by pseudomonas savastanoi in woody hosts. Frontiers in Plant Science, 8, e1089. https://doi.org/10.3389/fpls.2017.01089

Campos, A., da Costa, G., Coelho, A. V., \& Fevereiro, P. (2009). Identification of bacterial protein markers and enolase as a plant response protein in the infection of Olea europaea subsp. europaea by Pseudomonas savastanoi pv. savastanoi. European Journal of Plant Pathology, 125, e603. https://doi.org/10.1007/s10658-009-9509-0

Case, R. J., Boucher, Y., Dahllof, I., Holmstrom, C., Doolittle, W. F., \& Kjelleberg, S. (2007). Use of $16 \mathrm{~S}$ rRNA and $r p o B$ genes as molecular markers for microbial ecology studies. Applied and Environmental Microbiology, 73(1), 278-288. https://doi.org/10.1128/AEM.01177-06

EPPO. (2006). Pathogen-tested olive trees and rootstocks. EPPO Bulletin, 36, 77-83. https://doi.org/10.1111/j.1365-2338.2006.00912.x

Ghasemi, A., Salehi, S., Shahriari, D., \& Baniameri, V. (2006). Occurrence of oleander knot disease
(Nerium oleander) in Tehran. Iran Journal of Plant Pathology, 42, 703-704.

Hall, T. A. (1999). BioEdit: a user-friendly biological sequence alignment editor and analysis program for Windows 95/ 98/NT. Nucleic Acid Symposium Series, 41, 95-98.

Hassani, D., Buonaurio, R., \& Tombesi, A. (2003). Response of some olive cultivars, hybrid and open pollinated seedling to Pseudomonas savastanoi pv. savastanoi. In N. S. Iacobellis, A. Collmer, S. Hutcheson, J. Mansfield, C. E. Morris, J. Murillo, N. W. Schaad, ...(Eds.), Pseudomonas syringae and Related Pathogens (pp, 489-494). The Netherlands, Kluwer Academic Publishers. https://doi.org/10.1007/978-94-017-0133-4_54

Iacobellis, N. S. (2001). Olive knot. In O. C. Maloy \& T. D. Murray (Eds.), Encyclopedia of Plant Pathology (pp, 714-715). New York, NY: John Wiley \& Sons, Inc.

Kieffer, M., Neve, J., \& Kepinski, S. (2010). Defining auxin response contexts in plant development. Current Opinions in Plant Biology, 13, 12-20. https://doi.org/10.1016/j.pbi.2009.10.006

Kimura, M. (1980). A simple method for estimating evolutionary rate of base substitutions through comparative studies of nucleotide sequences. Journal of Molecular Evolution, 16, 111-120. https://doi.org/10.1007/BF01731581

Krid, S., Rhouma, A., Quesada, J. M., Penyalver, R., \& Gargouri, A, (2009). Delineation of Pseudomonas savastanoi pv. savastanoi strains isolated in Tunisia by random-amplified polymorphic DNA analysis. Journal of Applied Microbiology, 106, 886-894. https://doi.org/10.1111/j.1365-2672.2008.04058.x

Lelliott, R. A., Billing, E., \& Hayward, A. C. (1966). A determinative scheme for the fluorescent plant pathogenic pseudomonads. Journal of Applied Bacteriology, 29, 470-489. https://doi.org/10.1111/j.1365-2672.1966.tb03499.x 
Llop, P., Caruso, P., Cubero, J., Morente, C., \& Lopez, M. M. (1999). A simple extraction procedure for efficient routine detection of pathogenic bacteria in plant material by polymerase chain reaction. Journal of Microbiology Methods, 37, 23-31. https://doi.org/10.1016/S0167-7012(99)00033-0

Marcelo, A., Fernandes, M., Fatima Potes, M., \& Serrano, J. F. (1999). Reactions of some cultivars of Olea europaea L. to experimental inoculation with Pseudomonas syringae pv. savastanoi. Acta Horticulturae, $\quad 474$, 581-584. https://doi.org/10.17660/ActaHortic.1999.474.120

Marchi, G., Mori, B., Pollacci, P., Mencuccini, M., \& Surico, G. (2009). Systemic spread of Pseudomonas savastanoi pv. savastanoi in olive explants. Plant Pathology, 58, 152-158. https://doi.org/10.1111/j.1365-3059.2008.01935.x

Marchi, G., Viti, C., Giovannetti, L., \& Surico, G. (2005). Spread of levan-positive populations of Pseudomonas savastanoi pv. savastanoi, the causal agent of olive knot, in central Italy. European Journal of Plant Pathology, 112, 101-112. https://doi.org/10.1007/s10658-005-0804-0

Marques, D. S. A., \& Samson, R. (2016). Population dynamics of Pseudomonas savastanoi pv. phaseolicola in bean, throughout the epiphytic and pathogenic phases. Pesquisa Agropecuaria Brasileira, 51(5), 623-630. https://doi.org/10.1590/S0100204X2016000500024

Mehri, I., Turki, Y., Daly, I., Ben Rjab, A., Hassen, A., \& Gtar, M. (2013). Molecular identification and assessment of genetic diversity of fluorescent pseudomonads based on different polymerase chain reaction (PCR) methods. African Journal of Microbiology Research, 7(19), 2103-2113. https://doi.org/10.5897/AJMR12.2364

Moretti, C., Vinatzer, B. A., Onofri, A., Valentini, F., \& Buonaurio, R. (2017). Genetic and phenotypic diversity of Mediterranean populations of the olive knot pathogen, Pseudomonas savastanoi pv. savastanoi. Plant Pathology, 66, 595-605. https://doi.org/10.1111/ppa.12614

O’Brien, J. A., \& Benková, E. (2013). Cytokinin crosstalking during biotic and abiotic stress responses. Front in Plant Science, 4, e451. https://doi.org/10.3389/fpls.2013.00451

Patten, C. L., Blakney, A. J., \& Coulson, T. J. (2013). Activity, distribution and function of indole-3acetic acid biosynthetic pathways in bacteria. Critical Reviews in Microbiology, 39, 395-415. https://doi.org/10.3109/1040841X.2012.716819
Penyalver, R., Garcia, A., Ferrer, A., Bertolini, E., \& Lopez, M. M. (2000). Detection of Pseudomonas savastanoi pv. savastanoi in olive plants by enrichment and PCR. Applied and Environmental Microbiology, 66(6), 2673-2677. https://doi.org/10.1128/AEM.66.6.2673-2677.2000

Penyalver, R., Garcia, A., Ferrer, A., Bertolini, E., Quesada, J. M., Salcedo, C. I., ... Lopez , M. M. (2006). Factors affecting Pseudomonas savastanoi pv. savastanoi plant inoculations and their use for evaluation of olive cultivar susceptibility. Phytopathology, 96, 313-319. https://doi.org/10.1094/PHYTO-96-0313

Quesada, J. M., Garcia, A., Bertolini, E., Lopez, M. M., \& Penyalver, R. (2007). Recovery of Pseudomonas savastanoi pv. savastanoi from symptomless shoots of naturally infected olive trees. International Microbiology, 10, 77-84.

Quesada, J. M., Penyalver, R., Pérez-Panadés, J., Salcedo, C. I., Carbonell, E. A., \& López, M. M. (2010). Comparison of chemical treatments for reducing epiphytic Pseudomonas savastanoi pv. savastanoi populations and for improving subsequent control of olive knot disease. Crop Protection, 29, 1413-1420. https://doi.org/10.1016/j.cropro.2010.07.024

Rademaker, J. L. W., \& de Bruijn, F. J. (1997). Characterization and classification of microbes by Rep-PCR genomic fingerprinting and computer assisted pattern analysis. In: G. Caetano-Anollés, \& P. M. Gresshoff (Eds.), DNA Markers: Protocols, Applications and Overviews. New York, NY: John Wiley \& Sons, Inc.

Rajwar, A., \& Sahgal, M. (2016). Phylogenetic relationships of fluorescent pseudomonads deduced from the sequence analysis of $16 \mathrm{~S}$ rRNA, Pseudomonas-specific and rpoD genes. 3 Biotech. 6, e80. https://doi.org/10.1007/s13205-016-0386-X

Ramos, C., Matas, I. M., Bardaji, L., Aragon, I. M., \& Murillo, J. (2012). Pseudomonas savastanoi pv. savastanoi: some like it knot. Molecular Plant Pathology, 13, 998-1009. https://doi.org/10.1111/j.1364-3703.2012.00816.X

Renesto, P., Lorvellec-Guillon, K., Drancourt, M., \& Raoult, D. (2000). rpoB gene analysis as a novel strategy for identification of spirochetes from the genera Borrelia, Treponema, and Leptospira. Journal of Clinical Microbiology, 38(6), 22002203.

Rodriguez-Moreno, L., Jimenez, A. J., \& Ramos, C. (2009). Endopathogenic lifestyle of Pseudomonas savastanoi pv. savastanoi in olive knots. Microbial 
Biotechnology,
https://doi.org/10.1111/j.1751-7915.2009.00101.x

Saitou, N., \& Nei, M. (1987). The neighbor-joining method: a new method for reconstructing phylogenetic trees. Journal of Molecular Evolution, 4, 406-425.

Schaad, N. W., Jones, J. B., \& Chun, W. (2001). Laboratory Guide for Identification of Plant Pathogenic Bacteria. $3^{\text {th }}$ ed. Minnesota. MN: APS Press.

Sisto, A., Cipriani, M. G., \& Morea, M. (2004). Knot formation caused by Pseudomonas savastanoi subsp. savastanoi on olive plants is hrp-dependent. Phytopathology, 94, 484-489. https://doi.org/10.1094/PHYTO.2004.94.5.484

Spaepen, S., Vanderleyden, J., \& Remans, R. (2007). Indole-3-acetic acid in microbial and microorganism-plant signaling. FEMS Microbiology Reviews, 31, 425-448. https://doi.org/10.1111/j.1574-6976.2007.00072.x

Taghavi, M., \& Hasani, S. (2012). Occurrence of Pseudomonas savastanoi the causal agent of winter jasmine gall in Iran. Iran Agricultural Research, 31(1), 39-48.

Tamura, K., Dudley, J., Nei, M., \& Kumar, S. (2007). MEGA4: molecular evolutionary genetics analysis
(MEGA) software version 4.0. Molecular Biology and Evolution, 24, 1596-1599. https://doi.org/10.1093/molbev/msm092

Tayeb, L. A., Ageron, E., Grimont, F., \& Grimont, P. A. D. (2005). Molecular phylogeny of the genus Pseudomonas based on rpoB sequences and application for the identification of isolates. Research in Microbiology, 156, 763-773. https://doi.org/10.1016/j.resmic.2005.02.009

Tegli, S., Gori, A., Cerboneschi, M., \& Grazia Cipriani, M. (2011). Type three secretion systems in Pseudomonas savastanoi pathovars: does timing matter? Genes, 2, 957-979. https://doi.org/10.3390/genes2040957

Thompson, J. D., Higgins, D. G., \& Gibson, T. J. (1994). CLUSTALW: improving the sensitivity of progressive multiple sequence alignment through sequence weighting, position specific gap penalties and weight matrix choice. Nucleic Acids Research, 22 , 4673-4680. https://doi.org/10.1093/nar/22.22.4673

Weisburg, W. G., Barns, S. M., Pelletier, D. A., \& Lane, D. J. (1991). 16S ribosomal DNA amplification for phylogenetic study. Journal of Bacteriology, 173, 697-703. https://doi.org/10.1128/jb.173.2.697703.1991 